\title{
What Best Explains Successful Protest Cascades? ICTs and the Fuzzy Causes of the Arab Spring ${ }^{1}$
}

\author{
Muzammil M. Hussain \\ University of Washington
}

AND

\author{
Philip N. Howard \\ Princeton University
}

\begin{abstract}
It has been 15 years since the last wave of democratization. But as a region, North Africa and the Middle East were noticeably devoid of popular democracy movements - until the early months of 2011. Democratization movements had existed long before technologies like mobile phones and the Internet came to these countries. But with these technologies, people sharing an interest in democracy built extensive networks and activated collective action movements for political change. What might have made regimes more susceptible than others to these uprisings, and what might explain the relative successes of some movements over others? What role does information technology have in the modern recipe for democratization? Weighing multiple political, economic, demographic, and cultural conditions, we find that information infrastructure - especially mobile phone use-consistently appears as one of the key ingredients in parsimonious models for the conjoined combinations of causes behind regime fragility and social movement success. To understand the successes and failures of contemporary political protests, we must also assess how civil society leaders and authoritarian security forces treat communication technologies as democratically consequential.
\end{abstract}

Over the course of a year, popular movements for democracy cascaded across the Middle East and North Africa. These were not Marxist or Islamist movements, and while there was great diversity in the expectations for what democracy could look like, there was a shared fatigue with authoritarian rule. In the early days of protest in each country, the participants were unusual: they were not the urban poor, unionized labor, existing opposition party members, radical

\footnotetext{
${ }^{1}$ This research was supported by the Center for Information Technology Policy of the Woodrow Wilson School for International Affairs at Princeton University, the Center for Comparative and International Studies at ETH Zurich, and the National Science Foundation under award IIS-1144286, "RAPID-Social Computing and Political Transition in Tunisia." Any opinions, findings, and conclusions or recommendations expressed in this material are those of the authors and do not necessarily reflect the views of the National Science Foundation. For useful comments on earlier drafts of this work, we are grateful to Lance Bennett, Andrew Chadwick, Larry Diamond, Steve Livingston, and Frank Schimmelfennig. Replication data are available at the Web site of the Project on Information Technology and Political Islam, www.pitpi.org.

Hussain, Muzammil M. and Philip N. Howard. (2013) What Best Explains Successful Protest Cascades? ICTs and the Fuzzy Causes of the Arab Spring. International Studies Review, doi: 10.1111/misr.12020 (C) 2013 International Studies Association
} 
Islamists, or minorities with grievances. They were middle-class, educated, and underemployed, relatively leaderless, and technology-savvy youth. The gender balance also surprised many observers. In what has come to be called the "Arab Spring" by optimists, and the "Arab Revolts" by others, four dictators have been successfully deposed, a dozen other regimes have made major political and economic concessions, and political turmoil has devolved into civil war in several others.

By 2012, Egypt and Tunisia had run elections and were drafting fresh constitutions, and there were new Parliaments and Cabinets in Morocco and Jordan, with significant commitments to extend franchise. Even in Constitutional Monarchies where ruling families remained in control, a greatly expanded welfare state was the cost of the stability. Several countries are now governed by transitional governments with imperfect constitutions and predatory militaries. It will be years before we can judge the democratic practices of the new governments. But even in countries where Islamism is on the rise, the most viable Islamist leaders are competing in elections and advocating different brands of Islamic Constitutionalism. And what is surprisingly important is the powerful role of digital media in both socializing young people into the existing tropes of political dominance or revolution and in allowing young people to create new rhetorical tools - and often logistical tools - for challenging ideological control (Howard and Hussain 2013; Singh 2013).

For many observers, digital media appeared to have an important role in the ignition of social protest, the cascade of inspiring images and stories of success across the countries of the region, and the peculiar organizational form that Arab Spring uprisings had (Tufekci and Wilson 2012). For scholars of comparative politics, the distribution of outcomes suggest a need to take information technology seriously as a potentially causal factor: the two Arab Spring countries in which dictators were deposed relatively quickly, Tunisia and Egypt, had the most tech-savvy civil society and large Internet-using populations in the region; the two Arab spring countries in which dictators were deposed only after months of protracted civil war, Libya and Yemen, had no such character. What more can we say about the necessary or sufficient ingredients of successful cases where protest cascades resulted in relatively peaceful transitions away from decades of authoritarian rule? In contrast, which factors consistently predict failures, violence, or entrenchment of authoritarianism?

We build on a six-stage framework for political change observed during the early aftermath of the Arab Spring to understand the contextual variables that were in play before the Arab Spring (Howard and Hussain 2011). The most successful cases of sustained and peaceful protest, with deposed despots, were Tunisia and Egypt. Both cases exemplified a pattern that can be seen, with different degrees of strength, across the region: a preparation phase, involving activists' use of digital media across time to build solidarity networks and identification of collective identities and goals; an ignition phase, involving symbolically powerful moments which ruling elites and regimes intentionally or lazily ignored, but which galvanized the public; a protest phase, where, by employing offline networks and digital technologies, small groups strategically organized on large numbers; an international buy-in phase, where digital media networks extended the range of local coverage to international broadcast networks; a climax phase, where the regime maneuvered strategically or carelessly to appease public discontent through welfare packages or harsh repressive actions; and finally, a follow-on information warfare phase, where various actors, state-based and from international civic advocacy networks, compete to shape the future of civil society and information infrastructure that made it possible.

But this narrative of "digitally enabled" political change, though generalizable to many Arab Spring cases, does not account for some important technology-related 
factors that were in play as well. Moreover, it is tempting to follow this chronology of phases and begin anticipating what is next to come. It is important to recognize that successful uses of digital media across many cases of the Arab world are potentially counterbalanced by important instances where digital media, even when available, may not have been very useful. As we will demonstrate, digital media and information and communication technologies (ICTs) can also empower authoritarian security forces in improving their management and coercion capabilities. For example, the United Arab Emirates boasts some of the highest levels of connectivity and e-government development in the Arab world, but this country experienced hardly any successful offline mobilization. Some regimes, including Saudi Arabia, were very masterful in designing information censorship and management protocols nearing the sophistication of China and Iran. It is wrongheaded to construct a technologically deterministic theory of contemporary democratization, but it is good social science to critically assess the role of tools that have enabled both social movement leaders and empowered recalcitrant dictators.

\section{Communication Technologies and Political Change}

There have been few global studies of the contribution of different kinds of information technology toward democratization movements. In one of the largest of public opinion analyses, Nesbit et al. find that the Internet drives democratic expectations, especially in countries that already have a few democratic habits (Nisbet, Stoycheff, and Pearce 2012). Ever since the Zapatista rebels used the World Wide Web to promote their struggle for indigenous land rights in 1994, international analysts have been engaged in explaining the uses of digital technology by grassroots activists and social movements and determining the technologies' effects on political outcomes (Meikle 2002; Russell 2001, 2005). In years since, many have contributed valuable insights into this phenomenon in specific geographic and temporal contexts, sometimes focused on moments of heightened contention, such as national elections or social justice campaigns (Margolis, Resnick, and Tu 1997; Pedersen and Saglie 2005; Howard 2010; Sreberny and Khiabany 2010; Earl and Kimport 2011). Others have taken a thematic approach, viewing a specific phenomenon, such as digital authoritarianism, across a group of representative countries (Kalathil and Boas 2003). These scholars have drawn on qualitative and quantitative data and have written from a variety of subject perspectives, including sociology, communications, political science, computer science, and area studies. Yet all have been limited to a specific country or region and have a fairly limited time horizon.

Studies suggest that along with wealth, telecommunications and information policy can contribute to democratization (Norris 2001; Milner 2006; Howard and Mazaheri 2009). Many have hypothesized that increased Internet usage supports the growth of democratic institutions (Hogan 1999; Abbott 2001; George 2006). Yet both democracies and dictatorships have fast-growing numbers of Internet users, Internet hosts, mobile phones, and personal computers. Authoritarian regimes may develop their digital communication infrastructure specifically to extend state power (Kalathil and Boas 2003). There is significant research on the censorship strategies of the most authoritarian of Islamic states, but also evidence that a significant amount of digital content is beyond the reach of state censors (Diebert 2008). In democracies, there is some evidence that effective state services online breeds trust and confidence among citizens in their government (Hasan 2003; Welch, Hinnant, and Moon 2005; Tolbert and Mossberger 2006). As the experience of Iran in 2009 suggests, it may be the social media that is more immune to censorship than other salvages of civil society in repressive regimes. 
Indeed, there are lessons about civic action from Iran that may well be consistent with the Arab Spring and the global \#Occupy movements: digital technologies provide the entry points for young activists to explore democratic alternatives, an action landscape such as cyberspace that allows for political discourse and even direct interventions with state policy, and coordinating mechanisms that support synchronized social movements through marches, protests, and other forms of collective action (Kirsh 2001; Warschauer, El Said, and Zohry 2002; Abdulla 2005, 2007; Shapiro 2009). Perhaps the clearest signs that digital media has changed the dynamics of political communication come from the awkward ways authoritarian regimes have responded to its own tech-savvy activists. In pre-revolutionary Egypt, when Muhammad Khaled Said posted an online video incriminating the police in a drug deal, he was beaten to death outside of his Internet café, an event that precipitated a Facebook group that was critical in mobilizing elites during the revolution (York 2011).

While "terror on the Internet" and transnational Islamist identity has been well explored in the security studies literature, relatively little research has been done on the specific mechanisms of technology use and its repurposing by civil society actors. Understanding such mechanisms would help us answer broader questions about the nature of contemporary regime change, online participation, and the security implications of information policy (Bunt 2000, 2003, 2009; Weimann 2006). Some area studies and Islamist scholars have studied information technology diffusion and political practices in particular countries or investigated the impact of Al Jazeera on news cycles and sourcing (Rugh 2004; Alavi 2005; George 2006; Wheeler 2006). Information technologies are also the infrastructure for anti-democratic movements and the site of what some have called "cyberconflict" (Karatzogianni 2006). However, rigorous social science can build more transportable theories about the role of social computing during political crisis, and the role of social computing in civic life in the Muslim world. Cyberwar and cyber terror are not the only form of social computing in the service of political discourse (Stohl and Stohl 2007).

In the analytical discourse so far, there are two ways of describing the causes and consequences of the Arab Spring. The first analytical frame is to identify the things that make a country susceptible to protests or fragile enough for a popular uprising to ignite in the streets. The second is to identify the things that might explain a successful uprising. It would be wrong-headed to debate how many bloggers it takes to make a democracy. Rather than looking for simple or singular causal explanations for what made a country susceptible to popular uprisings or what allowed a popular uprising to achieve its goals, we should expect that there would be complex causal patterns or even several causal recipes that would provide analytical purchase over several sets of cases. Moreover, knowing what we know about social movements and regime change, it makes most sense to look for "conjoined causal conditions," the set of multiple indicators that together provide a fulfilling narrative for understanding political outcomes. An examination of the political impacts of digital technologies should not assume positive or negative effects. In fact, it should investigate the conditions and factors that most consistently explain democratic change or persistent authoritarianism. There is a rich body of growing literature on these issues - we seek to extend the tradition by comparatively examining this latest cascade of political change.

\section{The Comparative Method and Fuzzy Logic}

Comparative international researchers must deal with complex relationships between macrostructures, political cultures, and social transformations (Elkins 1979). There are two popular approaches by which this is often done, and these 
methodological preferences are often grounded in distinct epistemologies. The debates between the two are best manifested in the quantitative versus qualitative debate (see King, Keohane, and Verba 1994 or Ragin 2008, respectively, for both perspectives). In contrast, the Boolean algebra and set theory-based fuzzy set approach offer important advantages by combining the strengths of qualitative case knowledge but extending the range of explanation beyond one or two cases (Ragin 1987).

This uniquely comparative method combines some of the affordances of variable-oriented quantitative approaches with the strengths of case-oriented qualitative knowledge (Mahoney 2010). When applied to the Arab Spring, there have been a significant number of single-country case studies in which information technologies have been part of the contemporary narrative of both democratic entrenchment and persistent authoritarianism. The comparative perspective taken in our investigation will not be limited to the standard cases, or even to situations that stand out as incidents of technology-driven, enhanced, or enabled regime change. Instead, our comparative perspective embraces cases in which information technologies had little to no role in democratic promotion, as well as situations in which information technologies were carefully used by authoritarian elites to become better bullies, and situations in which information technologies played a critical role in sudden democratic transitions. Methodologically, this approach is powerful and productive in that it confronts theory with data. The set of cases at hand is the population of Arab countries with large Muslim communities, and there are 20 of these.

The argument of this investigation is that in recent years, information technologies have opened up new paths to democratization and the entrenchment of civil society in many Arab countries. Large-N quantitative researchers often turn "democratization" into an indicator for which the Western democracies are the standard. In our set-theoretic approach, we assume that democratization among these 20 countries is best calibrated according to a more regionally relevant standard, set at the high end by countries such as Lebanon and at the low end by countries such as Saudi Arabia. This calibration does not preclude the theoretical possibility of an Islamic democratic ideal type. But a grounded approach does assume that healthy, functional Muslim democracies may not look like Western democracies. Set-theoretic reasoning allows for fine gradations in the degree of membership in the set of successful democratic outcomes, and it requires evidence about each country's degree of membership in the set of countries that have experienced democratic transition or entrenchment during or since the Arab Spring.

Moreover, a set-theoretic explanation of the role of information technology in contemporary democratization requires that we identify a consistent set of causal relations between technology diffusion and democratic outcomes. To construct this explanation requires fuzzy set logic, which does not explain variation in a sample through reductive correlational statistics. The qualitative, empirical evidence reviewed lends itself to a set-theoretic argument, because the evidence revealed that many of the countries experiencing protests have high levels of technology diffusion and almost all experienced significant changes in their political systems. Identifying the causal conditions shared by cases that have further democratized is appropriate for identifying the necessary conditions of democratization.

It is possible that there are several recipes for contemporary democratization, and many possible ingredients and combinations of ingredients. One way to assemble the accumulated country experience is by comparing the recent histories of countries that share the common outcome of a significant period of democratic transition or entrenchment, such as in the Arab Spring. Analyzing the relationships in this set-theoretic manner exposes the key ingredients for 
democratization in a time-bound and qualitatively rich context. Moreover, treating the institutional outcomes as fuzzy sets avoids selecting cases on the outcome because countries will actually vary in their degree of membership in the set displaying democratic transition or entrenchment. Set theory allows us to examine cases with the same causal conditions to see whether they also share the same outcome. More important, if we assume that there is not just one recipe for contemporary democratization, but several, we can use fuzzy set analysis to identify combinations of causal conditions that share the same outcome.

\section{Causal Variables}

Several contextual factors might exacerbate or mitigate the causal role of particular aspects of technology diffusion, and reducing the set of causal attributes to a few important ones must also respect the significant diversity among these countries. The cases involved in the Arab Spring differ in important ways, yet there may still be causal patterns and shared attributes that explain membership in the set of countries that have democratized or not. Along with the impact of technology diffusion on the system of political communication involving states, journalists, political parties, civil society groups, and cultural elites, additional contextual conditions should also be evaluated on a case-by-case basis:

\section{Average Incomes Within Country}

Measured as GDP per capita (adjusted for purchasing power parity), this factor accounts for the large diversity in economic productivity across the region. The high end of this scale includes rich countries like Qatar, the UAE, Kuwait, and Bahrain (average range of $\$ 7,000-20,000$ ); the low end includes countries like Mauritania, Iraq, Comoros, and Somalia (average range of $\$ 200-800$ ).

\section{Wealth Distribution}

Measured as Gini coefficients for income distribution, this indicator reveals the relative deprivation of the poor in society. It captures the distinctions between countries like Lebanon and Qatar, where wealth is comparatively well distributed, and Egypt and the UAE, where wealth is highly concentrated.

\section{Levels of Unemployment}

Access to jobs may have been a primary source of discontent in Arab Spring countries, particularly in countries like Tunisia and Yemen where the formal unemployment rates topped 15 percent. Employment may also be a comparatively important variable because some of the countries with weak protest turnout had low unemployment rates. In Saudi Arabia, formal employment was hovering around 5 percent, and it was even lower in Kuwait. Youth unemployment is also a useful variable to include because of anecdotal evidence that the political uprisings were led by disaffected youth.

\section{Demographic Variables}

The causes of political unrest during the Arab Spring could be plausibly related to having large groups of disaffected citizens in densely packed urban settlements, so it is important to include measures of the size of the country in terms of population, the degree of urbanization, and youth bulge. Almost the entire population of Qatar and Kuwait lives in urban centers, while less than 40 percent of Yemen and Somalia's population does so. Yemen and Somalia also have the 
largest proportion of population under 25 years old-some 45 percent of the total population-while less than 25 percent of the population of Qatar and Kuwait is under 25 years old. Overall, the Arab Spring countries include both small island states with a few million inhabitants and countries like Egypt, with large populations.

\section{Digital Connectivity}

We measure digital connectivity in the diffusion of mobile telephone and Internet use. Interestingly, more than half of Arab countries have mobile penetration well over 100 percent, including several of the countries where Arab Spring protests were most successful. Internet penetration rates do not always mirror mobile phone penetration rates, however. While 54 percent of the population of Bahrain has Internet access, it is a country where the popular uprising was quickly crushed. Only 15 percent of Egyptians have access to the Internet, but in that country the dictator was successfully removed.

\section{Censorship Sophistication}

To counterbalance digital access and shared connectivity, many regimes in the Arab world have instituted censorship mechanisms that range widely in levels of sophistication. A few countries have very sophisticated monitoring and management systems, including Saudi Arabia, Bahrain, and the UAE. Others did not have the ability or failed to do so, including Algeria, Egypt, and Libya. To examine these cases comparatively, we created an index combining the OpenNet Initiative's monitoring of countries that had instituted no filtering, or a range of selective, substantial, and pervasive filtering on content for political, social, security reasons or used automated tools to do so. Our index combines these multiple dimensions of censorship and sophistication in filtering to assess the overall censorship regime's capacity for managing new information infrastructure.

\section{Fuel-dependent Economy}

Having access to the wealth generated by a fuel-dependent economy can allow ruling elites to maintain social control. Not having this wealth means authoritarian rules may not have the resources to maintain internal security services and co-opt political opponents. To account for this significant variable, we included countries' level of oil production and its share in the global oil resources available. Saudi Arabia, the UAE, and Kuwait ranked most highly.

\section{Outcome Variables}

Because our key research questions deal with the contextual factors and variables at play during the Arab Spring, many of our predictive variables listed above come from the latest data points available at or just before the protest periods. However, our overall objective is to find a parsimonious set of causes or conjoined causes that explain what made some Arab Spring regimes resistant to popular uprisings and then what made some popular uprisings successful.

\section{Regime Fragility}

This was evaluated by the relative numbers and impact of protest mobilizations in each of the countries of the Arab Spring. Full membership in the set of fragile Arab Spring countries was given to the countries where street turnout was surprisingly large, attendance was consistently high over several days, domestic 
media attention unusually interested, and protests took place in an unexpected number of diverse locations. Lower scores went to cases where protest turnout was small, concentrated in only a few locations, or protesters themselves were quickly dissuaded.

\section{Social Movement Success}

Outcomes were graded on a straightforward, comparative Guttman score for how successful protest organizers were at achieving the immediate goals of regime change. The highest scores went to cases that are fully in the set of countries where the titular head of government was deposed with minimal violencethese were the ideal cases of peaceful democratic regime change (Egypt and Tunisia). Below this are the countries where major political and economic concessions were made (Oman and Saudi Arabia), followed by major political concessions only (Kuwait and Jordan), followed by economic concessions only (Lebanon and Bahrain), and lastly countries that reached bloody civil wars and/ or violent stalemates with ruling elites (Libya and Syria). Long-term success in achieving economic, employment, or constitution writing goals was not evaluated. The fuzzy ranks for this variable took into account the detailed qualitative information for each case, including the longevity of protest, numbers of killed and injured citizens, types of meaningful political concessions, and levels of economic redistributions of wealth.

\section{Data Calibration}

We used data from 2011 or the best available year. ${ }^{2}$ Demographic and economic data came from sources like the United Nations Data Program, technology data came from the International Telecommunications Union, and political data came from primary data collected and synthesized by the authors. When the data taken from large data sets were incomplete, we supplemented data from secondary sources. Patching these gaps by hand significantly reduced the number of missing cases and provided for a more robust and meaningful ranking system. Preparing data for treatment as a fuzzy set required several steps. First, we computed indices for the plausible causal factors-which means converting the data into a number between 0 and 1 . Then, we calibrated the indices, a process that evens out the distribution of cases between the thresholds for full inclusion in each set, full exclusion from the set, and the crossover point at which cases go from being partially in the set to being partially out of the set. The variable of population size provides a useful example of how this process works. Among the 20 countries, there are a few very populated countries and many countries with a small population. Egypt, Iraq, and Saudi Arabia are at the top of this set and help define the category of "populated Arab Spring country."

Fuzzy calibrations also allow comparativists to complete incomplete data sets. In this study, there were four hand calibrations. There were no censorship scores for Djibouti, Mauritania, and Somalia, but secondary sources suggest that the level of censorship in Djibouti was much like that of Kuwait, that the level of censorship in Mauritania was higher than Lebanon's but not as a high as Jordan's, and that the level of censorship in Somalia was almost as high as that in Saudi Arabia. As another example, the final hand calibration involved designating a democracy-level score for Somalia. Polity IV data identifies Somalia as a

\footnotetext{
${ }^{2}$ The full data set of all variables in the causal recipes described in this investigation is available at www.pITPI org, as are the technical scripts for secondary solution sets not described here and the calibration points for specific membership sets. For more on fuzzy set calibrations, see the codebook for the fs/QCA 2.0 software and Ragin (2000).
} 
failed state in 2010. This case is not likely to teach us much about a theoretical relationship between political institutions, technology diffusion, and popular movements for democracy, so it was given a fuzzy score of 0.50 . This is a special score designating a case that is neither in nor out of the theoretical set of democracies. A score of 0.51 would mean that a country is very slightly in the theoretical set of democracies, and a score of 0.49 would mean that a country is just out of such a set. But the transition score signals that if regime type is important, Somalia is not a good instance of either a democracy or an autocracy. The fuzzy scores used in this analysis appear in Table 1.

\section{Recipes for Transition Failures and Successes}

Movement success is a qualitatively difficult judgment to make, but comparative analysis makes such judgments both possible and plausible. Many of the leaders and participants of the Arab Spring movements sought the removal of a longstanding dictator or a change in executive authority. Others primarily sought economic or political concessions, and most movements sought to achieve these things without state reprisals. Thus, the judgment of success should not only be about the degree to which a movement achieved their public policy goals, but whether they did so without arrests, torture, loss of life, or property damage, and did so in a relatively short period of time. Tunisia and Egypt probably define the theoretical set of "successful" Arab Spring movements, because it is in these countries where leaders were deposed relatively quickly and relatively peacefully. Libya's leader was deposed too, but with much more sacrifice and as of writing, Syria's position is precarious but has had a year of violence and civil war. In Jordan, Kuwait, Lebanon, Morocco, Oman, and Saudi Arabia, there were lesser successes and successes in different ways. In Algeria and Sudan, the Arab Spring movements were small and relatively humble. Comparatively speaking, the social movement mobilization was not only unsuccessful, the state reprisals were severe enough that the social movement collapsed under repression. Bahrain probably defines full non-membership in the theoretical set, because it is here that the

Table 1. Comparative Statistical Scores for Set Membership

\begin{tabular}{lllllllllll}
\hline Country & Gdppc & Gini & Unemp & Urban & Youth & Mobile & Internet & Fuel & Pol & Success \\
\hline Algeria & 0.58 & 0.37 & 0.42 & 0.47 & 0.32 & 0.47 & 0.32 & 1 & 0.83 & 0.55 \\
Bahrain & 0.84 & 0.42 & 0.58 & 0.89 & 0.26 & 0.68 & 0.89 & 0.58 & 0.11 & 0.2 \\
Djibouti & 0.16 & 0.74 & 1 & 0.63 & 0.74 & 0.05 & 0.16 & 0.01 & 0.83 & 0.3 \\
Egypt & 0.32 & 0.21 & 0.26 & 0.26 & 0.58 & 0.37 & 0.37 & 0.42 & 0.56 & 0.95 \\
Iraq & 0.05 & 0.11 & 0.74 & 0.42 & 0.89 & 0.42 & 0.79 & 0.37 & 0.94 & 0.3 \\
Jordan & 0.53 & 0.58 & 0.47 & 0.01 & 0.63 & 0.63 & 0.47 & 0.05 & 0.56 & 0.6 \\
Kuwait & 0.89 & 0.01 & 0.05 & 1 & 0.16 & 0.84 & 0.74 & 0.89 & 0.28 & 0.6 \\
Lebanon & 0.63 & 0.95 & 0.32 & 0.84 & 0.21 & 0.26 & 0.58 & 0.11 & 1 & 0.6 \\
Libya & 0.68 & 0.42 & 0.84 & 0.68 & 0.42 & 0.95 & 0.11 & 0.95 & 0.28 & 0.8 \\
Mauritania & 0.11 & 0.68 & 0.84 & 0.21 & 0.84 & 0.32 & 0.05 & 0.26 & 0.67 & 0.4 \\
Morocco & 0.42 & 0.79 & 0.37 & 0.37 & 0.37 & 0.53 & 0.68 & 0.21 & 0.44 & 0.6 \\
Oman & 0.79 & 0.21 & 0.58 & 0.58 & 0.47 & 0.89 & 0.84 & 0.68 & 0.11 & 0.6 \\
Qatar & 1 & 0.79 & 0.01 & 0.95 & 0.01 & 0.74 & 0.95 & 0.63 & 0.01 & 0.5 \\
Saudi & 0.74 & 0.21 & 0.16 & 0.74 & 0.53 & 1 & 0.47 & 0.79 & 0.01 & 0.6 \\
Somalia & 0.01 & 0.01 & 0.95 & 0.11 & 1 & 0.01 & 0.01 & 0.16 & 0.5 & 0.5 \\
Sudan & 0.26 & 1 & 0.79 & 0.16 & 0.79 & 0.11 & 0.21 & 0.74 & 0.67 & 0.55 \\
Syria & 0.37 & 0.42 & 0.21 & 0.32 & 0.68 & 0.21 & 0.42 & 0.47 & 0.28 & 0.7 \\
Tunisia & 0.47 & 0.79 & 0.53 & 0.53 & 0.11 & 0.58 & 0.63 & 0.32 & 0.5 & 0.95 \\
UAE & 0.95 & 0.11 & 0.11 & 0.79 & 0.05 & 0.79 & 1 & 0.53 & 0.11 & 0.4 \\
Yemen & 0.21 & 0.58 & 0.58 & 0.05 & 0.95 & 0.16 & 0.26 & 0.84 & 0.67 & 0.95 \\
\hline
\end{tabular}


state crackdown has been the toughest. By gradation, the relative failure of Arab Spring movements also means low scores for Djibouti, Iraq, Mauritania, and the UAE. Qatar and Somalia are transition cases - neither in nor out-because they had no significant popular uprising. Table 2 offers more of the details about each of the movement outcomes as of the publication of this article.

Each single Arab Spring country could be described with its unique combination of causal factors. Certainly, there are more complex formulations of conditions that would also explain the susceptibility of a regime to a popular uprising, or the chances such an uprising would be successful. The combinations reported here are not the only plausible ones, but the limited combinations that plausibly explain multiple cases with good coverage and consistency. Coverage refers to the percentage of cases explained by that recipe. Consistency refers to the degree to which cases adhere to a particular causal recipe. Since the goal of comparative work is sensible, parsimonious explanations, Table 3 presents four of the parsimonious models with the best balance of case coverage and solution consistency addressing the causal recipes of successes or failures of the Arab Spring movements. These recipes had the largest raw coverage of cases with good consistency. As a set, they explain half the cases with excellent consistency. Notably, several countries can be explained by several plausible causal recipes, and these recipes do not cover any unique cases on their own. The first causal combination includes being relatively authoritarian, not having a relatively fuel-dependent economy, many mobile phone users, or particularly high rates of unemployment. The second combination-with the highest raw coverage score-simply involves being an Arab Spring social movement in a country with no fuel-dependent economy or a youth bulge.

The third and fourth causal combinations introduce the Internet-use variable, on both occasions with a positive valence. Internet use contributes to movement success in countries where the unemployment rate is not particularly high or in countries where the level of wealth distribution is particularly unequal. This set of explanations is particularly powerful for explaining what happened in Egypt, Lebanon, Morocco, and Tunisia. Relative to the other countries involved in the Arab Spring, these are the best instances of these conjoined causal combinations. There are several interesting implications of these recipes. First, not being a country where the national economy is dependent on fuel exports is a consistent ingredient in all the recipes of social movement success. Second, widespread use of mobile phone technologies was less important for the success of social movements than Internet use. However, the latter does appear as a key ingredient in two causal recipes. Therefore, having a mobile-enabled population is useful, particularly when protests have been ignited. But more than access to mobile technologies, having a long-term Internet-enabled civil society appears in all recipes.

\section{Discussion}

Digital media were critical during the short-term cascade of street protests of the Arab Spring. We know that online conversations spiked before major events on the ground, as well as across the region (Howard et al. 2011). This was possible because social media helped democratic ideas spread across borders, through informal networks of families, friends, and interested onlookers. The intensity of political conversations that took place preceding major street protests supports the idea that virtual networks materialized before street protest networks. For example, detailed maps and guides were widely available before protests began, and provided would-be participants with strategies and nonviolence goals to sustain periods of dissent. Facebook pages and Twitter conversations were essential for designing and trying out new strategies as events took place on the ground. 


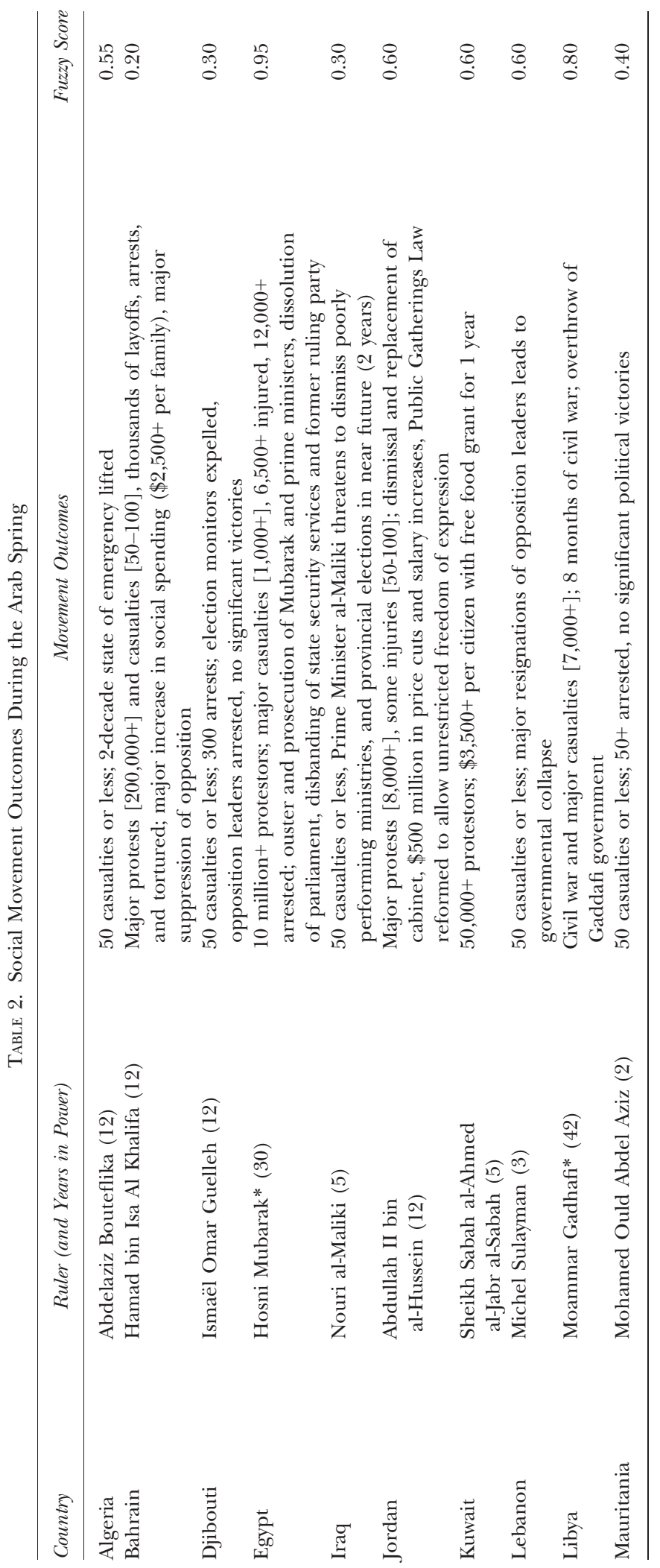




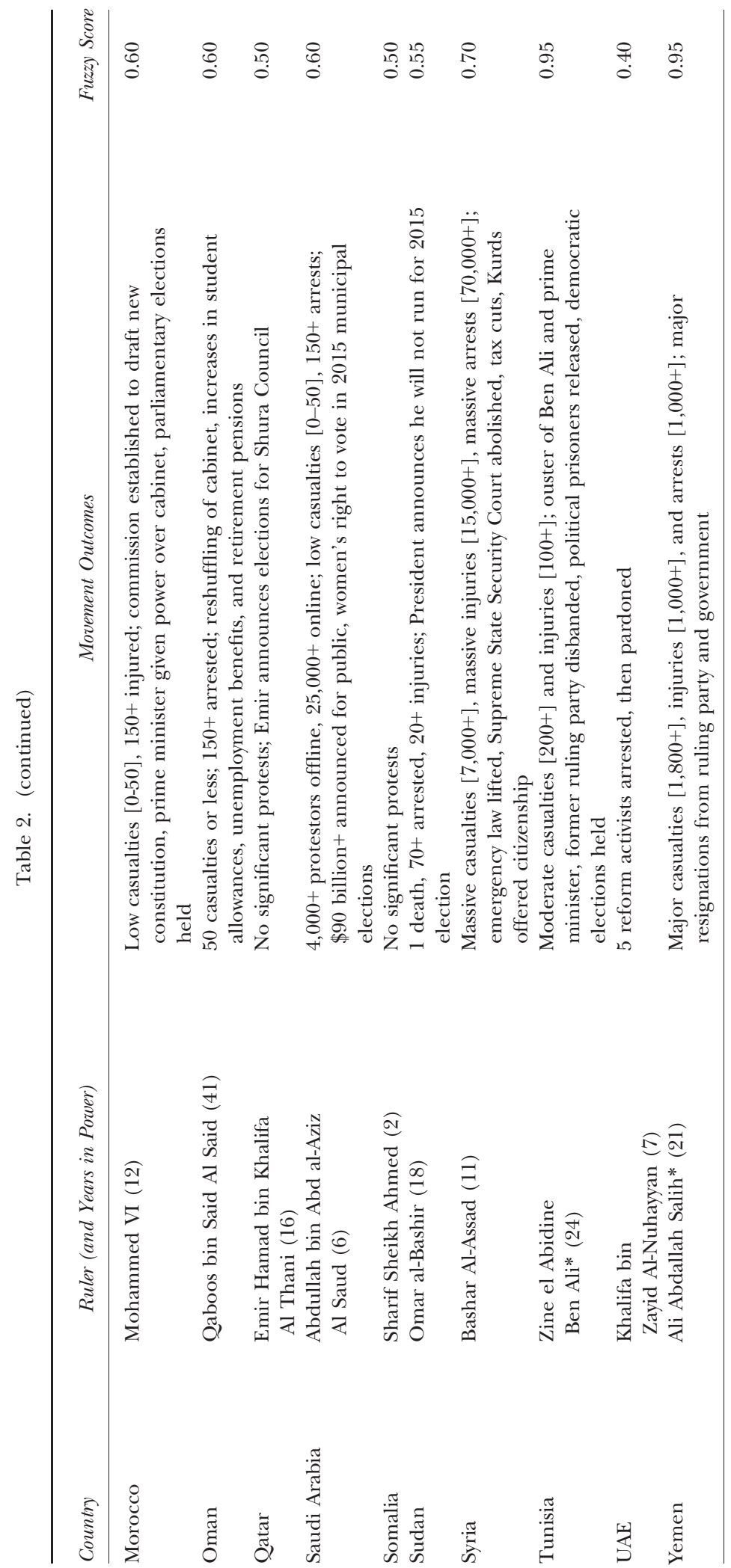


Table 3. Two Parsimonious Causal Recipes for Success of Arab Spring Movements

\begin{tabular}{|c|c|c|c|c|c|}
\hline $\begin{array}{l}\text { Variables } \\
\text { Included }\end{array}$ & Causal Recipe & $\begin{array}{c}\text { Raw } \\
\text { Coverage }\end{array}$ & $\begin{array}{c}\text { Unique } \\
\text { Coverage }\end{array}$ & Consistency & Best Instances \\
\hline \multirow{4}{*}{$\begin{array}{l}\text { Pol, fuel, } \\
\text { internet, } \\
\text { mobile, youth, } \\
\text { urban, unemp, } \\
\text { gini, gdppc }\end{array}$} & pol $^{*} \sim$ fuel $^{*} \sim$ mobile*$\sim$ unemp & 0.34 & 0.02 & 0.95 & $\begin{array}{l}\text { Lebanon }(0.68,0.6) \text {, } \\
\text { Egypt }(0.56,1)\end{array}$ \\
\hline & $\sim$ fuel $^{*} \sim$ youth & 0.45 & 0.00 & 0.87 & $\begin{array}{l}\text { Lebanon }(0.79,0.6) \text {, } \\
\text { Tunisia }(0.68,1), \\
\text { Morocco }(0.63,0.7)\end{array}$ \\
\hline & $\sim$ fuel*internet* $*$ unemp & 0.44 & 0.00 & 0.91 & $\begin{array}{c}\text { Morocco }(0.63,0.7) \\
\text { Lebanon }(0.58,0.6)\end{array}$ \\
\hline & $\sim$ fuel*internet*gini & 0.40 & 0.00 & 0.91 & $\begin{array}{c}\text { Morocco }(0.68,0.7) \text {, } \\
\text { Tunisia }(0.63,1), \\
\text { Lebanon }(0.58,0.6)\end{array}$ \\
\hline
\end{tabular}

Notes. These causal recipes are the parsimonious solution set with a cutoff point set at 0.954 . Altogether, the solution coverage is 0.51 and solution consistency is 0.89 .

Political blogospheres, many based nationally, but others also based more regionally, connected with political diaspora communities from France, the UK, and other Western democratic countries (Etling et al. 2010). The ability to produce and consume political content was important because it created a sense of shared grievances, and strong political efficacy that had not led to such sizable, diverse, and quick mobilization before the Arab Spring.

However, it would be a mistake to suggest the democratic potential of information technologies without considering its full range of roles, especially regimes' management and manipulations of these tools. There are several regimes that have very sophisticated strategies to effectively co-opt or coerce technology providers. One of the key threats to authoritarian regimes is elite defection. Therefore, some regimes, like Saudi Arabia and the UAE, follow a closely guarded, systematic, and well-financed strategy to monitor and punish online acts of political engagement. Others, like Egypt and Jordan, tolerated such incidents by assuming that some venting of political dissatisfaction could be ventilated online and therefore not materialize substantively offline. When dissatisfaction did eventually spill over, security forces took a range of measures to suppress the political application of digital media. During extreme circumstances, entire global information networks were taken offline. This strategy backfired, causing street protests to increase in numbers, especially in Egypt, where individuals turned to traditional institutions to find each other, such as after Friday prayer services in Cairo. Disconnecting large information networks also cost Egypt \$18 million USD per day by blocking global financial transactions. Digital media, in their presence and absence, are politically consequential-but are they simply a new "tool" for social protest? Or is there more that needs to be said about the modern character of political protests?

For scholars of social movements and collective action, there are several interesting aspects of the Arab Spring: the distributed leadership of protest organizers, the core groups of elite publics (literate, middle class, youth, women, and technocrats) that were relatively quick in joining them, and the important role that international news organizations played in giving them the global exposure to help stave off overtly violent reactions from security forces. We can say more than that the Internet changed the way political actors communicatedsocial movement leaders and collective action networks shared strategies for direct political action, created regional and international news events that drew attention and sympathy from neighboring countries, and inspired others to join and celebrate their causes. Counterfactual scenarios are important, but the overwhelming evidence of what did happen concretely illustrates that the 
patterns of political change in these protests were digitally enabled. One of the key reasons why we must now turn our attention to the role of information technology is that citizens themselves have expressed its role, and remaining authoritarian regimes are treating it as a critical threat to their power and stability.

We must also consider the years leading up to the Arab Spring, and the diffusion of digital media, in the form of mobile phones, personal computers, and software applications over time. These technologies and their applications have significantly impacted the political communication systems and their relationships to civil society organizations. First, mobile telephony, in the form of small consumer-based communication devices, has allowed regular citizens to bear witness, record, and disseminate acts of injustice and repression by their ruling elites and security forces. In important ways, authoritarian regimes to hold phony elections also gained widespread infamy, particularly in the Egyptian elections of 2005, where Mubarak's party won 89 percent of the vote. Mobile videos uploaded to YouTube and other video-sharing sites disseminated actual footage of vote counting and rigging. Second, over the last five years, Al Jazeera became a functionally independent regional news organization, and with the addition of the English-language network in 2006, an international powerhouse that illuminated the accusations, criticisms, and failures of autocrats. Third, widespread Internet access, though limited to middle-class urban-dwellers, offered everyday citizens to synthesize social networks with broadcast networks to communicate and engage with political issues. Together, these long-term trends mean that information infrastructure helped decentralize state power, especially regimes that were not quick enough to adapt their management strategies to regulate these new political information spaces.

Digital media had a causal role in the Arab Spring in that they provided the fundamental infrastructure of a social movement unlike the others that have emerged in recent years in these countries. In the first few weeks of protest in each country, the generation of people in the streets - and its leadership-was clearly not interested in the three major models of political Islam. These social movements were not seeking to replace secular dictatorships with Al Qaeda's Salafi Jihadism, Iran's Shiite theocracy, or Saudi's rigid Wahhabism (Wright 2011). Instead, these mostly cosmopolitan and younger generations of mobilizers felt disenfranchised by their political systems, saw vast losses in the poor management of national economies and development (Ramadan 2012), and most importantly, a consistent and widely shared narrative of common grievances - a narrative which they learned about from each other and co-wrote on the digital spaces of political writing and venting on blogs, videos shared on Facebook and Twitter, and comment board discussions on international news sites like Al Jazeera and the BBC.

The causes of revolution are always complex, and the conditions under which revolts succeed are rare. For a revolution to succeed, the government must seem so unjust and inept that it is viewed as a threat to the country's future. A country's social, economic, and military elites must be alienated from the state and no longer willing to defend it, which was true with Egypt and Tunisia in the deposition of their dictators, but less so with Libya and Syria, and not so with Bahrain and Saudi Arabia. The regime's opponents must also build consensus across a broad swath of the population, crossing ethnic, religious, and class groups, which has been varied across the Arab Spring cases, but certainly bolstered with the diffusion of mobile and digital media networks (Goldstone 2011). Finally, international powers must either refuse to step in and defend the government, or must constrain the government from defending itself too ruthlessly. The Arab Spring, then, is historically unique because it is the first set of political upheavals in which most of these things were digitally mediated. 
Many of the dictators who have held on to power in the Middle East and North Africa have done so by telling their population, their neighbors, and the international community that they were the guardians against Islamist revolution. Some Islamist parties may have benefitted from the Arab Spring, like in the recent elections of Tunisia and Egypt, but these leaders did not lead the uprisings. In fact, they have categorically hesitated to join them until victory and political change was close to a real possibility. Among the countries in the region, those with high rates of technology diffusion and a significant, tech-savvy, and young civil society were the ones where the Arab Spring was most successful, along with regimes that had not mastered the art of managing information infrastructure. The countries with the lowest rates of technology diffusion, or a fragmented civil society with few technology resources, had less successful uprisings. Some of these later countries, including Libya, Syria, and Yemen, did experience extended civil war, but the inciting incidents of political strife, again, were digitally mediated. But on the whole, the role of digital media in the political unrest of these countries was not as pronounced as it was in Tunisia, Egypt, and Morocco, all of which experienced major political concessions ranging from democratic regime change or the uplifting of political sanctions and replacement of ruling elites.

The argument devaluing the complex causal role of digital media in the Arab Spring is often made through the simple claim that it is people, and their grievances, that constitute political revolution. Pundits have made this claim in different ways, but it is not helpful in improving our understanding of why contemporary protest cascades are faster, and sometimes more successful, than before. It is true that Facebook and Twitter did not cause revolutions, but it is bad analysis to ignore the strategic and intentional uses of digital media in political ways. Digitally networked activists have initiated some of the largest protests this decade in Iran, the temporary lifting of the Egyptian blockade on Gaza, and the global Occupy Wall Street movement. Digital media had a causal role in the Arab Spring by providing the very infrastructure that created deep communication ties and organizational capacity in groups of activists before the major protests took place. Digital media are what regimes in turn have invested millions in learning to censor and manage more effectively, with lessons drawn directly from the Arab Spring.

Social media is also the reason we have such good documentation of events. It is the reason that Egyptians had such live coverage of what was going on in Tunisia, and also the reason that Moroccans, Jordanians, and Yemenis had coverage of what was going on in Egypt, just as Libyans and Syrians had coverage of what was going on in those countries, and so on. In other words, it was social media that brought the narrative of successful social protest across multiple, previously closed, authoritarian media systems. When things did not go well, as in the case of Bahrain and Libya, activists in the continuing cascade took note and applied these lessons - just as authoritarian regimes, like Syria and Bahrain, have made interesting moves in opening up previously embargoed digital networks to better monitor the strategies and activities of protestors. For the most part, it was physical intimidation that discouraged activists from communicating about their political activity on Facebook. But these regimes also invested in their social media strategy, actively employed people to create pro-government content to distribute over social media networks, and attacked social movement leaders after identifying them in activists' online photographs.

Perhaps the most compelling reason for not dismissing the important causal role of digital media in the Arab Spring is that the traditional analysis, privileging other factors, yields uncompelling explanations (Gause 2011). For example, The Economist magazine built an index of how press freedom, corruption, democratic institutions, income, the youth bulge, and years of authoritarian rule 
might predict the vulnerabilities of particular regimes. But indexes like these suggested that Yemen, Libya, Syria, and Iraq were the most vulnerable. Yet they are neither the inciting nor defining cases of the Arab Spring. Yemen, Libya, and Syria had a small elite of technology activists who helped spread the word of successful rebellion in other countries, but the tough authoritarian regimes responded quickly and forcefully and with their own digital media strategy. These countries descended into months of civil strife, and did not see a rapid or peaceful regime transition. The countries that experienced rapid and relatively peaceful regime collapse, or where regimes made major concessions, did not appear particularly vulnerable - for example Egypt and Tunisia, or Saudi Arabia and Morocco, respectively.

Social media and information infrastructure make useful contributions toward social movement organizing and the mobilization of popular protest. A peripheral counting of media use and digital diffusion levels reveals that the countries experiencing the most dramatic changes had low overall percentages of social media use (Mourtada and Salem 2011). But limiting the analysis to aggregate indicators precludes the possibility of telling a more complex, causal story. Moreover, if there is anything to the analytical frame of networks, the use of important media by a few important nodes of users could be exceptionally consequential. This is why, to unpack the complexities of the Arab Spring, we must employ analytic approaches that make possible the examination of complex social systems that constitute the overall aggregate of state-based cases.

Street protests were the most challenging manifestations of political opposition for each regime's security forces, and they were certainly bolstered by decadeslong economic and political disenfranchisement of their citizens. Yet the millions of individuals on the streets of capital cities around the region were not disconnected individuals, and they also shared some generalizable similarities like large young populations that were open to broader engagement tactics than possible with the more traditional Islamist frameworks of previous generations. In fact the opposite is true-these protesters were very connected, in groups and networks. Not every Tunisian and Egyptian had access to a computer. But mobile phones were the key mediating instrument bridging the communication gaps: they could be easily carried and concealed, could often be used to shoot and upload photos and videos, and could be recharged in the street. Given the high rates of mobile phone use, especially in the dense urban centers, it is safe to say that each person at the protests either had a mobile phone, or was part of a group in which there were several mobile civic journalists and bloggers.

Before the Arab Spring, most social movement theorists had landed on a straightforward way of describing the importance of digital media. Digital media affected the costs and benefits of action, the opportunities and constraints on actor commitment, and was one of many resources available to activist leaders (Earl and Kimport 2011). In Bimber's account "socio-technological devices do not determine political outcomes, but simply alter the matrix of opportunities and costs associated with intermediation, mobilization and the organization of politics" (Bimber 2003:231). But the Arab Spring has demonstrated that digital media are tools with which activist leaders evaluate costs and benefits, but also a fundament infrastructure that varied political actors make use of in intended and democratically consequential ways.

\section{Conclusion}

What might have made regimes more susceptible than others to popular uprisings, and what might explain the relative successes of some movements more than others? What role does information technology have in the modern recipe for democratization? 
Long-term democratic entrenchment might come from truth-based online advocacy, constituent mobilization, and crowd-sourced social monitoring (Fung, Gilman, and Shkabatur 2013). Until the Arab Spring, much of the scholarly research on the political impact of digital media over the last decade supported this perspective (Howard 2010). But this comparative analysis demonstrates that digital media may also have a role in rapid political transformations. Weighing multiple political, economic, and cultural conditions, we find that information infrastructure - especially mobile phone use-consistently appears as one of the key ingredients in parsimonious models for the conjoined combinations of causes behind regime fragility and social movement success. Internet use is relevant in some solution sets, but by causal logic it is actually the absence of Internet use that explains low levels of success by Arab Spring movements.

In every single case, the inciting incidents of the Arab Spring were digitally mediated in some way. Information infrastructure, in the form of mobile phones, personal computers, and social media, were part of the causal story we must tell about the Arab Spring. People were inspired to protest for many different and always personal reasons. Information technologies mediated that inspiration, such that the revolutions followed each other by a few weeks and had notably similar patterns. Certainly there were different political outcomes, but that does not diminish the important role of digital media in the Arab Spring. It is precisely a reason why we must understand which configurations of information infrastructure can best serve the needs of democratic activists. It is also why authoritarian states have learned important lessons in how best to reconfigure their management of their telecommunications industries and censorship protocols. But even more importantly, this investigation has illustrated that countries that do not have a civil society equipped with digital scaffolding are much less likely to experience popular movements for democracy-an observation we are able to make only by accounting for the constellation of causal variables that existed before the street protests began, not simply the short-term uses of digital technologies during the short period of political upheaval.

\section{References}

Аввотт, Jason. (2001) Democracy@internet.asia? The Challenges to the Emancipatory Potential of the Net: Lessons from China and Malaysia. Third World Quarterly 22(1): 99-114.

Abdulla, Rasha A. (2005) Taking the E-train: The Development of the Internet in Egypt. Global Media and Communication 1(2): 149-165.

Abdulla, Rasha A. (2007) The Internet in the Arab World: Egypt and Beyond. New York: Peter Lang.

Alavi, Nasrin. (2005) We Are Iran: The Persian Blogs. Vancouver: Soft Skull Press.

Bimber, Bruce A. (2003) Information and American Democracy: Technology in the Evolution of Political Power. Cambridge, UK: Cambridge University Press.

Bunt, Gary R. (2000) Virtually Islamic: Computer-Mediated Communication and Cyber Islamic Environments. Cardiff, UK: University of Wales Press.

Bunt, Gary R. (2003) Islam in the Digital Age: E-Jihad, Online Fatwas and Cyber Islamic Environments. Critical Studies on Islam. London, UK: Pluto Press.

Bunt, GaRY R. (2009) iMuslims: Rewiring the House of Islam. Islamic Civilization and Muslim Networks. Chapel Hill, NC: University of North Carolina Press.

Diebert, Ronald. (2008) "The Geopolitics of Internet Control." In Routledge Handbook of Internet Politics, edited by Andrew Chadwick, and Philip N. Howard. London, UK: Routledge.

Earl, Jennifer, and Katrina Kimport. (2011) Digitally Enabled Social Change: Activism in the Internet Age. 1st ed. Cambridge, MA: MIT Press.

Elkins D. (1979) A Cause in Search of Its Effect, or What Does Political Culture Explain? Comparative Politics 11(2): 127-145.

Etling, Bruce, John Kelly, Robert Faris, and John Palfrey. (2010) Mapping the Arabic Blogosphere: Politics and Dissent Online. New Media Eo Society 12(8): 1225-1243.

Fung, Archon, Hollie Russon Gilman, and Jennifer Shkabatur. (2013). Six Models for the Internet + Politics. International Studies Review, 15(1): 30-47. 
Gause III, F. Gregory. (2011) Why Middle East Studies Missed the Arab Spring. Foreign Affairs, June 1. Available at http://www.foreignaffairs.com/articles/67932/f-gregory-gause-iii/why-middle-eaststudies-missed-the-arab-spring (Accessed January 17, 2012).

George, Cherian. (2006) Contentious Journalism and the Internet: Towards Democratic Discourse in Malaysia and Singapore. Singapore: Singapore University Press in association with University of Washington Press.

Goldstone, Jack. (2011) Understanding the Revolutions of 2011. Foreign Affairs 90 (3): 8.

HASAN, SADIK. (2003) Introducing e-government in Bangladesh: Problems and Prospects. International Social Science Review 79 (3-4): 111.

Hogan, Sarah. (1999) To Net or Not to Net: Singapore's Regulation of the Internet. Federal Communications Law Journal 51 (2): 429-446.

Howard, Philip N. (2010) The Digital Origins of Dictatorship and Democracy: Information Technology and Political Islam. New York: Oxford University Press.

Howard, Philip N., and Muzammil M. Hussain. (2011) The Upheavals In Egypt and Tunisia: The Role of Digital Media. Journal of Democracy 22(3): 35-48.

Howard, Philip N., And Muzammil M. Hussain. (2013) Democracy's Fourth Wave? Digital Media and the Arab Spring. New York: Oxford University Press.

Howard, Philip N., And Nimah Mazaheri. (2009) Telecommunications Reform, Internet Use and Mobile Phone Adoption in the Developing World. World Development 37(7): 1159-1169.

Howard, Philip N., Aiden Duffy, Deen Freelon, Muzammil M. Hussain, William Mari, and Marwa Mazaid. (2011) Opening Closed Regimes: What Was the Role of Social Media During the Arab Spring? National Science Foundation-funded Information Technology and Political Islam Project. Seattle, WA: Center for Communication and Civic Engagement.

Kalathil, Shanthi, and Taylor C. Boas. (2003) Open Networks, Closed Regimes: The Impact of the Internet on Authoritarian Rule. Washington, DC: Carnegie Endowment for International Peace.

Karatzogianni, Athina. (2006) The Politics of Cyberconflict. Routledge Research in Information Technology and Society. London, UK: Routledge. http://www.loc.gov/catdir/toc/ecip068/ 2006005549.html http://www.loc.gov/catdir/enhancements/fy0654/2006005549-d.html.

King, G., Keohane R. O., and Verba S. (1994) Designing Social Inquiry: Scientific Inference in Qualitative Research. Princeton, NJ: Princeton University Press.

Kirsh, David. (2001) The Context of Work. Human-Computer Interaction 16(2): 305-322.

Mahoney, J. (2010) After KKV: The New Methodology of Qualitative Research. World Politics 62(1): $120-147$.

Margolis, Michael, David Resnick, and Chin-chang Tu. 1997 Campaigning on the Internet. The Harvard International Journal of Press/Politics 2 (1): 59-78.

Meikle, Graham. (2002) Future Active: Media Activism and the Internet. New York: Psychology Press.

Milner, Helen. (2006) The Digital Divide: The Role of Political Institutions in Technology Diffusion. Comparative Political Studies 39 (2): 176-199.

Mourtada Racha, and Fadi Salem. (2011) Arab Social Media Report, Vol. 1. Dubai, UAE: Dubai School of Government.

Nisbet, Erik C., Elizabeth Stoycheff, and Katy E. Pearce. (2012) Internet Use and Democratic Demands: A Multinational, Multilevel Model of Internet Use and Citizen Attitudes about Democracy. Journal of Communication 62 (2): 249-265.

Norris, Pippa. (2001) Digital Divide: Civic Engagement, Information Poverty, and the Internet Worldwide. Communication, Society, and Politics. Cambridge, NY: Cambridge University Press.

Pedersen, Karina, and Jo Saglie. (2005) New Technology in Ageing Parties. Party Politics 11 (3): 359-377. doi:10.1177/1354068805051782.

Ragin, C. C. (1987) The Comparative Method: Moving Beyond Qualitative and Quantitative Strategies. Berkeley, CA: University of California Press.

Ragin, Charles C. 2000 Fuzzy-Set Social Science. 1st ed. Chicago: University of Chicago Press.

Ragin, C. C. (2008) Redesigning Social Inquiry: Fuzzy Sets and Beyond. Chicago: University of Chicago Press.

Ramadan, TARiQ. (2012) Islam and the Arab Awakening. New York: Oxford University Press.

Rugh, William (2004) Arab Mass Media: Newspapers, Radio, and Television in Arab Politics. Westport, CT: Praeger Publisher.

Russell, Adrienne. (2001) The Zapatistas Online. International Communication Gazette 63 (5): 399 413.

Russell, Adrienne. (2005) Myth and the Zapatista Movement: Exploring a Network Identity. New Media $\mathcal{E}$ Society 7(4): 559-577. 
Shapiro, Samantha M. (2009) Revolution, Facebook-Style. New York Times Magazine. http://www. nytimes.com/2009/01/25/magazine/25bloggers-t.html.

SingH, J. P. (2013) Information Technologies, Meta-power, and Transformations in Global Politics. International Studies Review 15(1): 5-29.

Sreberny, A., and G. Khiabany. (2010) Blogistan: The Internet and Politics in Iran. New York: I. B. Tauris.

Stohl, Cynthia, and Michael Stohl. (2007) Networks of Terror: Theoretical Assumptions and Pragmatic Consequences. Communication Theory 17 (2): 93-124.

Tolbert C., And K. Mossberger. (2006) The Effects of E-Government on Trust and Confidence in Government. Public Administration Review 66(3): 354-369.

Tufekci, Zeynep, and Christopher Wilson. (2012) Social Media and the Decision to Participate in Political Protest: Observations from Tahrir Square. Journal of Communication 62 (2): 363-379.

Warschauer, Mark, Ghada R. El Said, and Ayman Zohry. (2002) Language Choice Online: Globalization and Identity in Egypt. Journal of Computer-Mediated Communication 7 (4). http:// jcmc.indiana.edu/vol7/issue4/warschauer.html.

Weimann, Gabriel. (2006) Terror On the Internet: The New Arena, The New Challenges. Washington, DC: United States Institute of Peace.

Welch, E., C. Hinnant, and J. Moon. (2005) Linking Citizen Satisfaction with E-Government with Trust in Government. Journal of Public Administration Research and Theory 15(3): 371-391.

Wheeler, Deborah L. (2006) The Internet and the Middle East: Global Expectations and Local Imaginations in Kuwait. SUNY Series in Computer-Mediated Communication. Albany, NY: SUNY Press.

Wright, Robin. (2011) The Pink Hijab. The Wilson Quarterly Summer: 47-51.

York, Jillian. (2011) How Are Protestors in Egypt Using Social Media? Jilliancyork. http:// jilliancyork.com/2011/01/27/how-are-protestors-in-egypt-using-social-media/. 